\title{
Kajian Unit Pengolahan Menggunakan Media Berbutir dengan Parameter Kekeruhan, TSS, Senyawa Organik dan $\mathbf{p H}$
}

\author{
Suprihanto Notodarmodjo, Andriani Astuti \& Anne Juliah \\ Departemen Teknik Lingkungan, Fakultas Teknik Sipil dan Perencanaan \\ Institut Teknologi Bandung \\ Jl. Ganesha 10 Bandung, 40132
}

\begin{abstract}
Abstrak. Penelitian ini menguji kemungkinan penggunaaan instalasi menggunakan Flokulator dan Koagulator media berbutir dalam pengolahan air minum dalam skala lapangan. Reaktor yang digunakan berupa pipa PVC yang diisi kerikil dengan diameter rata-rata 2,025 cm. Air baku yang dialirkan merupakan air baku PDAM Badak Singa Bandung. Koagulan yang dipergunakan adalah PAC (Poly Aluminium Chloride). Hasil penelitian menunjukkan bahwa reaktor mampu menurunkan konsentrasi organik sampai 3,02 $\mathrm{mg} / \mathrm{L}$ dengan effisiensi penyisihan mencapai 73,17\%. Dan menurunkan kekeruhan sampai 0,5 NTU dengan effisiensi mencapai 96\%. Nilai Gtd untuk mencapai kondisi di atas adalah 6946, yang jauh dibawah nilai G.td yang biasanya diaplikasikan pada flokulator hidrolis. Dapat disimpulkan bahwa reaktor yang diuji memberikan hasil yang baik.
\end{abstract}

Kata Kunci: flokulasi; koagulasi; media berbutir.

\begin{abstract}
A field trial of flocculation using gravel bed has been done using PDAM's Kota Bandung as the location. The reactor used a PVC pipe that consisted of an average diameter of 2,025 cm gravel. PDAM's raw water was used as throughout the experiment. As coagulant, PAC (Poly Alumunium Chloride) is used. The results show that the reactor can reduce the organic content down to $3,02 \mathrm{mg} / \mathrm{L}$ with the removal efficiency up to $73,17 \%$. And it also can reduce the turbidity down to 0,5 NTU with removal efficiency up to $96 \%$. The G.td value was 6946 , which down below the average G.td used in hydraulic flocculation. Overall, the flocculation has a prospect to be used in operational scale.
\end{abstract}

Keywords: coagulation; flocculation; gravel bed.

\section{$1 \quad$ Pendahuluan}

Air permukaan merupakan sumber yang potensial untuk memenuhi kebutuhan air bersih bagi masyarakat karena jumlahnya yang berlimpah. Namun, kualitasnya secara umum lebih rendah dibanding sumber-sumber air lainnya sehingga menuntut pengolahan yang juga lebih lengkap. Dalam pengolahan air 
minum terutama yang berasal dari air permukaan, menghilangkan atau menurunkan zat padat baik tersuspensi maupun koloidal yang menyebabkan kekeruhan merupakan hal yang sangat penting. Partikel koloid menjadi stabil karena bermuatan listrik yang sama sehingga timbul gaya tolak antar partikel. Umumnya muatan koloidal alami yang berasal dari mineral liat mempunyai muatan negatif pada kondisi yang dijumpai di alam.

Dalam pengolahan air minum, partikel koloid ini disisihkan dengan cara koagulasi-flokulasi. Proses koagulasi dilakukan dengan penambahan bahan kimia sebagai koagulan, dan dilakukan pengadukan cepat, untuk membentuk flok yang dapat diendapkan. Pada prinsipnya, penambahan koagulan berfungsi untuk menetralkan muatan partikel dan memperkecil ketebalan lapisan difus di sekitar partikel sehingga mempermudah penggabungan partikel tersebut menjadi agregat yang lebih basar dan secara teknis dapat diendapkan (Stumm \& Morgan, 1996).

\subsection{Proses Koagulasi-Flokulasi}

Cara mendestabilkan partikel dilakukan dalam dua tahap. Pertama dengan mengurangi muatan elektrostatis sehingga menurunkan nilai potensial zeta dari koloid, proses ini lazim disebut sebagai koagulasi. Kedua adalah memberikan kesempatan kepada partikel untuk saling bertumbukan dan bergabung, cara ini dapat dilakukan dengan cara pengadukan, dan disebut sebagai flokulasi.

Pengurangan muatan elektris dilakukan dengan menambahkan koagulan seperti PAC. Di dalam air PAC akan terdisosisi melepaskan kation $\mathrm{Al}^{3+}$ yang akan menurunkan zeta potensial dari partikel. Sehingga gaya tolak-menolak antar partikel menjadi berkurang, akibatnya penambahan gaya mekanis seperti pengadukan akan mempermudah terjadinya tumbukan yang akan dilanjutkan dengan penggabungan partikel-partikel yang akan membentuk flok yang berukuran lebih besar.

Menurut Von Smoluchowski (Fair, et al, 1968), kecepatan penggabungan dua partikel dengan diameter berbeda akan sebanding dengan konsentrasi partikel, gradien kecepatan dan jumlah jari-jari dari partikel yang bergabung.

$$
J_{k l}=\frac{1}{6} n_{k} \cdot n_{l}\left(d_{k}+d_{i}\right)^{3} \frac{d v}{d z}
$$

Dalam persamaan diatas, $J_{k l}$ adalah banyaknya tumbukan (volume per waktu), $n_{k}$ dan $n_{l}$ adalah banyaknya partikel $k$ dan $l, d_{k}$ dan $d_{l}$ adalah diameter partikel $k$ dan $l$, serta $d v / d z$ adalah gradien geseran yang dapat diganti dengan $G$ (gradien kecepatan). 
Koagulasi dan flokulasi adalah proses fisika-kimia dimana diperlukan energi dan waktu agar proses dapat berlangsung, Camp dan Stein mengembangkan persamaan untuk menghitung besar energi dan waktu dengan konsep gradien kecepatan $(G)$ sebagai berikut (Reynold,1982):

$$
G=\sqrt{\frac{\varepsilon}{\mu}}=\sqrt{\frac{P}{\mu C}}=\sqrt{\frac{Q \cdot \rho \cdot g \cdot h_{f}}{\mu C}}
$$

dimana:

$$
\begin{array}{ll}
G & =\text { Gradien kecepatan, detik }{ }^{-1} \\
P & =\text { daya yang diberikan, } \mathrm{kg} \mathrm{m}^{2} / \mathrm{dtk}^{3},(\mathrm{~J} / \text { detik }) \\
\mu & =\text { viskositas absolut zat cair, } \mathrm{kg} / \mathrm{m} / \text { detik } \\
C & =\text { kapasitas reaktor, } \mathrm{m}^{3} \\
\varepsilon & =\text { total daya yang ditimbulkan per satuan massa cairan } \\
\rho & =\text { massa jenis air, } \mathrm{kg} / \mathrm{m}^{3} \\
g & =\text { kecepatan gravitasi, } \mathrm{m} / \mathrm{detik}^{2} \\
h_{f} & =\text { kehilangan tekanan yang terjadi, } \mathrm{m} \\
t d & =\text { waktu detensi, detik }
\end{array}
$$

Flokulasi merupakan kelanjutan dari proses koagulasi, dimana mikroflok hasil koagulasi mulai menggumpalkan partikel menjadi flok-flok yang besar (makroflok) dan dapat diendapkan. Proses penggumpalan ini tergantung dari waktu dan pengadukan lambat dalam air.

Flokulator yang sering digunakan dalam pengolahan air berdasarkan sumber

\begin{tabular}{|c|c|c|c|c|c|}
\hline $\begin{array}{c}\text { Jenis } \\
\text { Flokulator }\end{array}$ & $\begin{array}{c}\text { Energi input } \\
(\mathrm{hp} ; \mathrm{kw})\end{array}$ & $\begin{array}{c}\mathbf{G} \\
\left(\text { detik }^{-1}\right)\end{array}$ & $\begin{array}{c}\text { Td } \\
\text { (menit) }\end{array}$ & $\begin{array}{c}\mathbf{v} \\
(\mathbf{f p s})\end{array}$ & $\begin{array}{c}\mathbf{P} \\
\text { (psi) }\end{array}$ \\
\hline Hidrolis & $\mathrm{P}=\mathrm{Q} \rho g h$ & $20-50$ & $10-60$ & $0,5-1,5$ & - \\
\hline Pneumatis & $\begin{array}{l}\mathrm{P}=81,5 \mathrm{xQ}_{\mathrm{a}} \\
\log [(\mathrm{h}+34) / 34]\end{array}$ & $20-75$ & - & 1 & $50-75$ \\
\hline Mekanis & $P=1 / 2 C_{D} \rho A v^{3}$ & $20-75$ & $15-20$ & $1-2,5$ & - \\
\hline
\end{tabular}
energi yang digunakan adalah: hidrolis, pnuematis dan mekanis. Secara umum flokulator pneumatis dan mekanis lebih fleksibel dalam power input. Sedangkan flokulator hidrolis tidak fleksibel dalam power input, dimana diperlukan lahan yang luas walaupun mempunyai keunggulan pada sisi yang lain. Kriteria desain untuk masing -masing jenis flokulator disajikan dalam tabel 1. Energi input dari masing-masing jenis flokulator dihitung dengan rumus yang berbeda. Harga gradien kecepatan mempunyai jangkauan yang hampir sama, antara $20-70$ / detik. Kecepatan aliran bervariasi antara $0,5-2,5$ fps. Tekanan udara yang dibutuhkan untuk flokulator pneumatis antara $50-75$ psi.

Sumber : Fair,et al (1968) : ASCE, AWWA, (1990); dan Kawamura, (1991)

Tabel 1 Kriteria desain yang umum digunakan dalam rancangan flokulator. 


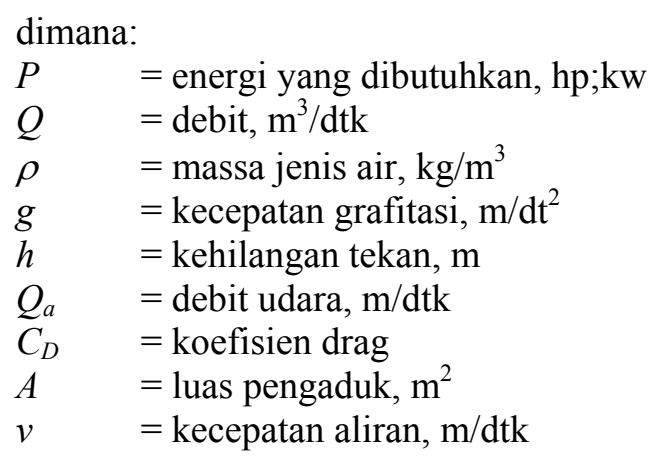

Pada umumnya flokulasi hidrolis mempunyai kekurangan dalam hal fleksibilitas pengaturan $h_{f}$ yang diperlukan sebagai energi untuk proses. Selain itu pada flokulator hidrolis, perbedaan kecepatan aliran yang terjadi pada bagian tepi dan tengah reaktor sangat besar, sehingga seringkali flok yang terjadi pecah kembali. Notodarmodjo et al (1998) telah meneliti kemungkinan penggunaan aliran melalui kerikil sebagai media untuk flokulator dengan hasil yang sangat baik. Armundito (2000) meneliti lebih jauh kemungkinan penggunaan media kerikil sebagai flokulator dan memperoleh hasil bahwa ukuran butir kerikil tidak berpengaruh secara nyata bagi pembentukan flok.

Tujuan dari tulisan ini adalah menyajikan hasil uji coba instalasi pengolahan air minum yang menggunakan teknologi alternatif dalam bentuk clarifier. Clarifier merupakan penggabungan proses flokulasi dan sedimentasi flok dalam suatu reaktor. Dalam unit flokulasi aliran melalui kerikil digunakan sebagai media untuk menghasilkan flok. Uji dilakukan di PDAM Kota Bandung.

\subsection{Hidrolika Aliran Melalui Media Berbutir}

Perhitungan headloss dengan persamaan Kozeny yang dikembangkan dari persamaan Darcy untuk aliran laminer adalah sebagai berikut:

$$
h_{f}=\frac{k \cdot v \cdot v_{d}(1-n)^{2}}{g \cdot n^{3}}\left(\frac{6}{\psi d}\right)^{2} L
$$

dimana :

$k \quad=$ koefisien kozeny, tak berdimensi

$v \quad=$ kekentalan kinetik $\left(\mathrm{m}^{2} / \mathrm{dtk}\right)$

$n \quad=$ porositas

$v_{d} \quad=$ kecepatan Darcy $(\mathrm{m} / \mathrm{dtk})$

$\psi \quad=$ faktor sperisitas, tak berdimensi

$d \quad=$ dimeter kerikil rata-rata $(\mathrm{m})$

$L \quad=$ panjang media dimana air mengalir $(\mathrm{m})$ 
$g \quad=$ kecepatan grapitasi $\left(\mathrm{m} / \mathrm{dtk}^{2}\right)$

Sedangkan jika bilangan Reynold $\mathrm{N}_{\mathrm{Re}}>10$, maka persamaannya menjadi (Bear dan Verruijt dari Notodarmodjo, 1998):

$$
h_{f}=L \frac{v \cdot v_{d}}{g \cdot f}+\frac{0,55 v_{d}^{2}}{g \sqrt{f}} L
$$

dimana $f$ merupakan porositas efektif.

\section{Metodologi Penelitian}

Penelitian dilakukan di PDAM Kota Bandung Sedangkan pemeriksaan kualitas air dilakukan di laboratorium Penelitian Departemen Teknik Lingkungan ITB .

\subsection{Instalasi dan Bahan yang Digunakan}

\subsubsection{Instalasi}

Koagulator berupa kerikil dalam sebuah pipa PVC 0,2 m sepanjang $3 \mathrm{~m}$ yang diletakkan vertikal. Dari koagulator aliran dibagi menjadi dua menuju dua flokulator yang masing-masing berupa pipa PVC 0,2 m dengan panjang $1,5 \mathrm{~m}$ yang berisi kerikil (Gambar 14). Sedimentasi merupakan suatu sistem up-flow pada pipa PVC $0,3 \mathrm{~m}$ sepanjang $1,5 \mathrm{~m}$, dimana arah aliran berasal dari bawah menuju ke atas Filter yang digunakan terdiri dari dua buah pipa PVC $0,3 \mathrm{~m}$ setinggi 1,5 m yang berisi kerikil setebal $20 \mathrm{~cm}$ sebagai media penyangga dan diatasnya berisi pasir setebal $70 \mathrm{~cm}$.

Untuk mengetahui kehilangan tekan dipasang piezometer yang terbuat dari selang plastik dengan diameter $4 \mathrm{~mm}$. Untuk pembacaan muka air dalam piezometer, ujung bebas dari poezometer ditempelkan pada papan yang dilengkapi kertas grafik. Air baku dialirkan dari tangki penampungan menuju koagulator. Sebelum masuk koagulator PAC diinjeksikan dengan bantuan dossing pump.

\subsubsection{Air Baku}

Air baku diambil langsung dari air baku PDAM Kota Bandung di Jl. Badak Singa. Air tersebut merupakan pencampuran dari air Sungai Cikapundung (200-600 L/dtk) dan air Sungai Cisangkuy (1300 L/dtk). Karena air baku merupakan air permukaan, maka kualitasnya berubah-ubah. 


\begin{tabular}{|c|c|c|c|c|c|}
\hline No & Parameter Analisa & Satuan & $\begin{array}{c}\text { Baku } \\
\text { Mutu } \\
\text { Air } \\
\text { Bersih }\end{array}$ & $\begin{array}{c}\text { Hasil } \\
\text { Analisa }\end{array}$ & Metode \\
\hline & FISIKA & & & & \\
\hline $\begin{array}{l}1 \\
2 \\
3 \\
4 \\
5 \\
6 \\
7 \\
8\end{array}$ & $\begin{array}{l}\text { Bau } \\
\text { Jumlah Zat padat } \\
\text { Terlarut (TDS) } \\
\text { Kekeruhan } \\
\text { Rasa } \\
\text { Suhu } \\
\text { Warna } \\
\text { Zat Padat Tersuspensi }\end{array}$ & $\begin{array}{l}- \\
\mathrm{mg} / \mathrm{L} \\
\mathrm{NTU} \\
- \\
{ }^{\circ} \mathrm{C} \\
\mathrm{TCU} \\
\mathrm{mg} / \mathrm{L}\end{array}$ & $\begin{array}{l}1000 \\
5 \\
- \\
\text { Udara } \\
+3^{\circ} \mathrm{C} \\
15 \\
50\end{array}$ & $\begin{array}{l}\text { Tidak berbau } \\
154 \\
120,6 \\
\text { Tidak berasa } \\
26 \\
87,5 \text { koloid } \\
0,27\end{array}$ & $\begin{array}{l}\text { Organoleptik } \\
\text { Gravimetri } \\
\text { Turbidity } \\
\text { Visual } \\
\text { Termometer } \\
\text { Kolorimeter } \\
\text { Gravimetri }\end{array}$ \\
\hline \multirow{2}{*}{8} & KIMIA & & & & \\
\hline & \multicolumn{2}{|l|}{ A. KIMIA ANORGANIK } & & & \\
\hline $\begin{array}{c}1 \\
2 \\
3 \\
4 \\
5 \\
6 \\
7 \\
8 \\
9 \\
10 \\
11 \\
\end{array}$ & $\begin{array}{l}\text { Besi }(\mathrm{Fe}) \\
\text { Kesadahan }(\mathrm{CaCO} 3) \\
\text { Klorida }(\mathrm{Cl}) \\
\text { Mangan }(\mathrm{Mn}) \\
\text { Natrium }(\mathrm{Na}) \\
\text { PH } \\
\text { Sulfat (SO4) } \\
\text { Kalium (K) } \\
\text { Kalsium (Ca) } \\
\text { MBAS } \\
\text { COD }\end{array}$ & $\begin{array}{l}\mathrm{mg} / \mathrm{L} \\
\mathrm{mg} / \mathrm{L} \\
\mathrm{mg} / \mathrm{L} \\
\mathrm{mg} / \mathrm{L} \\
\mathrm{mg} / \mathrm{L} \\
- \\
\mathrm{mg} / \mathrm{L} \\
\mathrm{mg} / \mathrm{L} \\
\mathrm{mg} / \mathrm{L} \\
\mathrm{mg} / \mathrm{L} \\
\mathrm{mg} / \mathrm{L}\end{array}$ & $\begin{array}{l}0,3 \\
500 \\
250 \\
0,1 \\
- \\
6,5-9,0 \\
400 \\
- \\
- \\
200 \\
10 \\
\end{array}$ & $\begin{array}{l}9,0 \\
73,3 \\
12,61 \\
0,36 \\
11,88 \\
7,29 \\
3,58 \\
3,57 \\
22,77 \\
0,524 \\
17,56 \\
\end{array}$ & $\begin{array}{l}\text { Spektrometri } \\
\text { Titrimetri } \\
\text { Titrimetri } \\
\text { Spektrometri } \\
\text { Flamephotometri } \\
\text { Elektrometri } \\
\text { Spektrometri } \\
\text { Flamephotometri } \\
\text { Titrimetri } \\
\text { Spektrometri } \\
\text { Titrimetri } \\
\end{array}$ \\
\hline 11 & B. KIMIA ORGANIK & & & & \\
\hline \multirow[t]{2}{*}{1} & Zat Organik (KMnO4) & & 10 & 37,21 & Titrimetri \\
\hline & LAIN-LAIN & & & & \\
\hline $\begin{array}{l}1 \\
2 \\
3 \\
4\end{array}$ & $\begin{array}{l}\text { Karbon dioksida }(\mathrm{CO} 2) \\
\text { total } \\
\text { Karbon dioksida }(\mathrm{CO} 2) \\
\text { agresif } \\
\text { Logam berat (kualitatif) } \\
\text { Bikarbonat (HCO3) } \\
\end{array}$ & $\begin{array}{l}\mathrm{mg} / \mathrm{L} \\
\mathrm{mg} / \mathrm{L} \\
- \\
\mathrm{mg} / \mathrm{L}\end{array}$ & $\begin{array}{l}- \\
- \\
- \\
-\end{array}$ & $\begin{array}{l}8,8 \\
5,8 \\
\text { negatif } \\
114,6\end{array}$ & $\begin{array}{l}\text { Titrimetri } \\
\text { Titrimetri } \\
- \\
\text { Titrimetri }\end{array}$ \\
\hline
\end{tabular}

Tabel 2 Kualitas air baku PDAM Badak Singa Bandung bulan September 2002.

Pada gambar 1 terlihat bahwa pada musim kemarau kekeruhan cenderung lebih rendah dan lebih stabil dibandingkan dengan musim hujan yang jatuh pada bulan september sampai maret. Sedangkan tabel 2 menyajikan hasil analisa terhadap air baku PDAM Badak Singa Bandung. Hampir semua parameter telah memenuhi standar baku mutu air bersih, kecuali untuk parameter kekeruhan, zat organik, kadar Besi serta Mangan. 


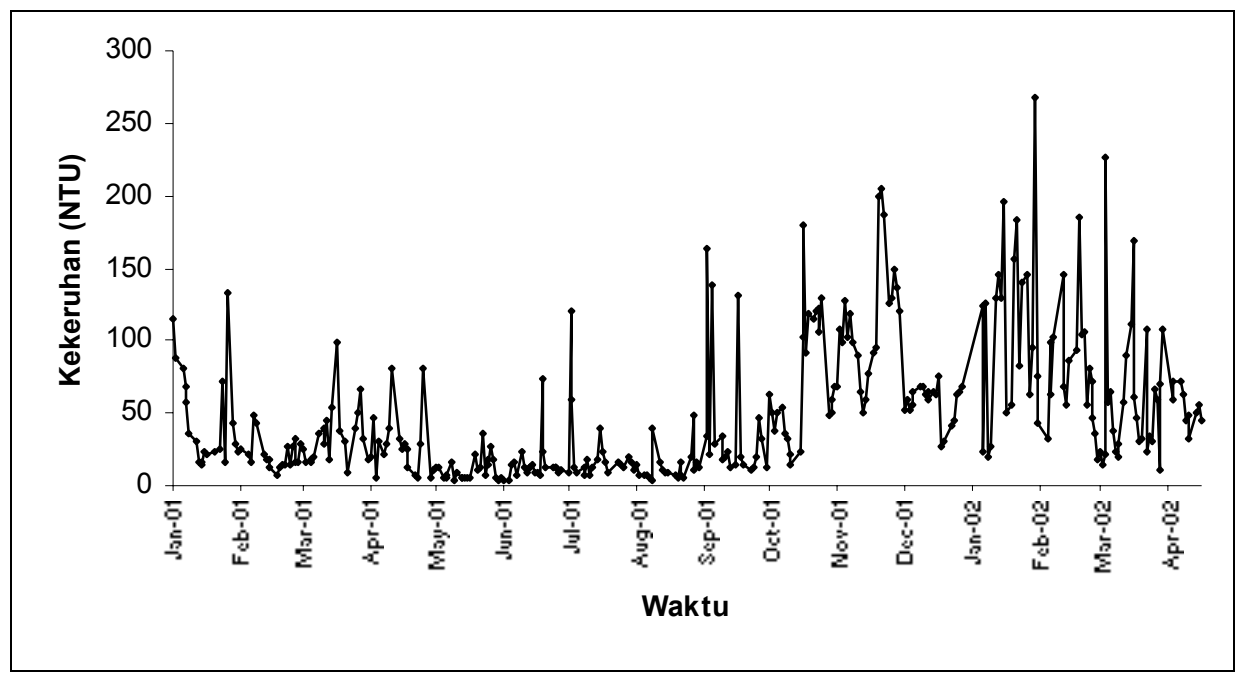

Gambar 1 Fluktuasi kekeruhan air baku PDAM Badak Singa.

\subsubsection{Media}

Media yang digunakan adalah media kerikil yang mempunyai karakteristik sebagai berikut:

$\begin{array}{ll}\text { - porositas } & =0,5 \\ \text { - bentuk } & =\text { angular } \\ \text { - sphericity } & =0,78 \\ \text { - faktor bentuk } & =7,7 \\ \text { - diameter rata-rata } & =2,025 \mathrm{~cm}\end{array}$

\subsubsection{Koagulan}

Koagulan yang digunakan pada penelitian ini adalah Poly Alumunium Chloride (PAC) teknis. Dosis koagulan yang dibutuhkan ditentukan dengan melakukan percobaan jar-test. Dari percobaan tersebut didapat dosis koagulan optimum untuk pengolahan air baku PDAM adalah $15 \mathrm{mg} / \mathrm{L}$.

\subsection{Prosedur Penelitian}

Air baku dipompa menuju bak penampungan sementara. Dari bak ini air dialirkan menuju koagulator melalui pipa. Pada pipa tersebut diinjeksikan koagulan dengan bantuan dossing pump. Dari koagulator air dialikan ke Clarifier yang didalamnya terdapat flokulator. Pengolahan terakhir dilakukan oleh filter sebelum akhirnya air hasil pengolahan dapat diambil.

Sampling dilakukan pada beberapa titik, yaitu: 
a. Titik satu: sebelum air masuk reaktor, pada bak pengumpul air baku PDAM.

b. Titik dua: pada outlet clarifier reaktor 1

c. Titik tiga: outlet clarifier reaktor 2

d. Titik empat: outlet filter 1

e. Titik lima: outlet filter 2

Pengambilan sampel dilakukan dengan menggunakan botol air mineral ukuran $600 \mathrm{~mL}$ yang sebelumnya telah dibersihkan. Pengambilan sampel dan pengukuran parameter dilakukan secara duplo. Pengamatan kehilangan tekan atau head-loss dilakukan melalui piezometer.

Pada penelitian ini dilakukan variasi debit untuk mengetahui sejauh mana reaktor masih dapat bekerja dengan baik. Debit yang dipergunakan adalah 0,05 $\mathrm{L} / \mathrm{dtk}, 0,1 \mathrm{~L} / \mathrm{dtk}$, dan $0,15 \mathrm{~L} / \mathrm{dtk}$. Variasi debit diperlukan karena debit menuju reaktor akan mempengaruhi variabel dalam persamaan (1) dan (2) secara langsung. Debit akan mempengaruhi kecepatan aliran antar pori yang akan mempengaruhi head loss (kehilangan tekan), seperti terlihat dalam persamaan (3) dan (4). Kehilangan tekan $\left(\mathrm{h}_{\mathrm{f}}\right)$ akan mempengaruhi daya yang terdisipasi (P) yang digunakan dalam mempercepat proses flokulasi (Tabel 1). Kecepatan yang terlalu tinggi juga akan membuat flok pecah akibat gaya geser yang berlebih. Selain itu kecepatan akan mempengaruhi waktu detensi yang diperlukan oleh proses flokulasi. Sebagai suatu proses, koagulasi juga dipengaruhi oleh waktu.

Parameter yang diamati dalam penelitian ini adalah kekeruhan, TSS, kandungan organik dan $\mathrm{pH}$.

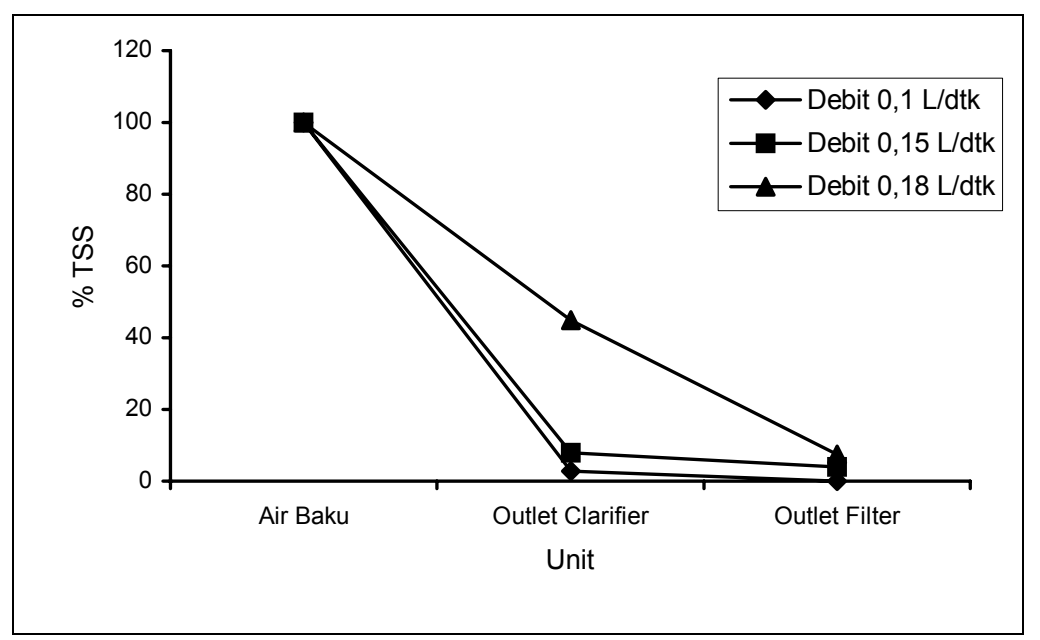

Gambar 2 Grafik penyisihan TSS pada berbagai variasi debit. 


\section{$3 \quad$ Hasil dan Pembahasan}

\subsection{Penurunan Kekeruhan, TSS, Zat Organik dan pH}

Dari gambar 2 terlihat effisiensi Penyisihan TSS telah mencapai lebih dari $89,9 \%$ pada outlet clarifier. Hasil ini mununjukan bahwa sebagian besar flok telah terendapkan di clarifier sehingga beban pengolahan filter menjadi berkurang dan filter dapat beroperasi dalam jangka waktu yang lebih lama sebelum akhirnya harus di backwash. Effisiensi ini bisa menjadi sangat tinggi karena pada clarifier terbentuk "selimut lumpur" (sludge blanket) yang terjadi akibat flok yang terjadi melayang karena terjadi keseimbangan kecepatan pengendapan dengan kecepatan aliran keatas. Keberadaan selimut lumpur mengakibatkan terjadinya kontak filtrasi yang mampu menyaring flok-flok yang berukuran kecil sehingga tidak terbawa aliran.

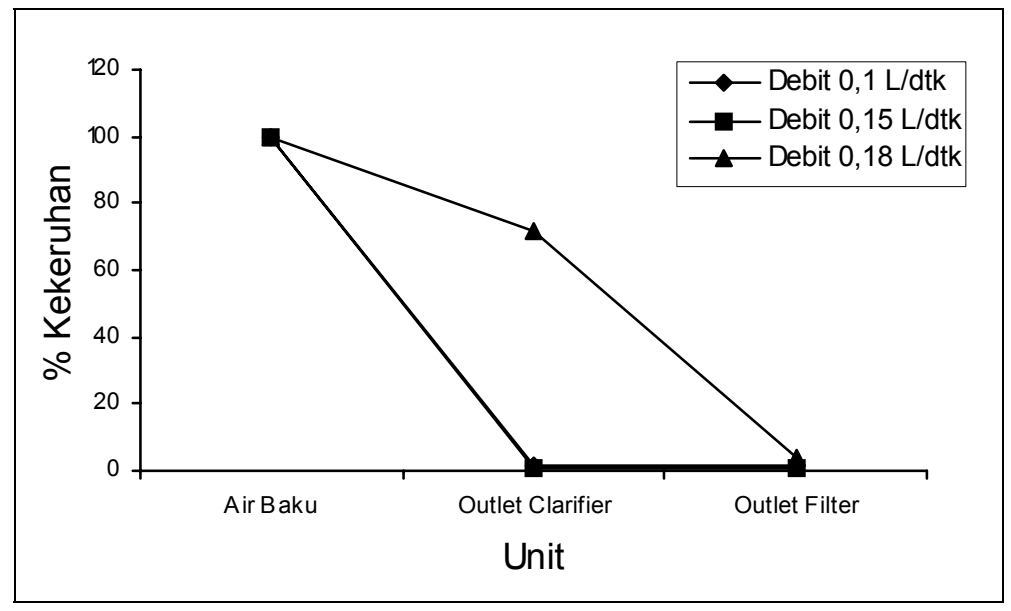

Gambar 3 Grafik penyisihan kekeruhan pada berbagai variasi debit.

Kualitas air hasil olahan pada debit $0,1 \mathrm{~L} / \mathrm{dtk}$ dan $0,15 \mathrm{~L} / \mathrm{dtk}$ menunjukkan hasil yang baik, yaitu masing-masing 0,5 NTU dan 0,2 NTU. Nilai ini dibawah standar kualitas air minum 5 NTU. Penyisihan kekeruhan tertinggi terjadi pada debit $0,15 \mathrm{~L} / \mathrm{dtk}$, karena nilai $G$ pada flokulator debit ini merupakan yang tertinggi dibandingkan nilai $G$ pada debit-debit lainnya, yaitu 21/dtk. Penyisihan organik pada outlet clarifier mencapai penyisihan $73 \%(2,995 \mathrm{mg} / \mathrm{L})$. Nilai ini telah memenuhi baku mutu air bersih golongan A berdasarkan Peraturan Pemerintah No. 20 tahun 1990 yaitu kurang dari 10 mg/L.

Pada outlet clarifier terjadi penurunan $\mathrm{pH}$. $\mathrm{pH}$ kembali meningkat setelah melalui filter. $\mathrm{pH}$ pad outlet filter berkisar antara 7,1 sampai 7,5, dan nilai tersebut telah memenuhi syarat air bersih golongan $\mathrm{A}$. 


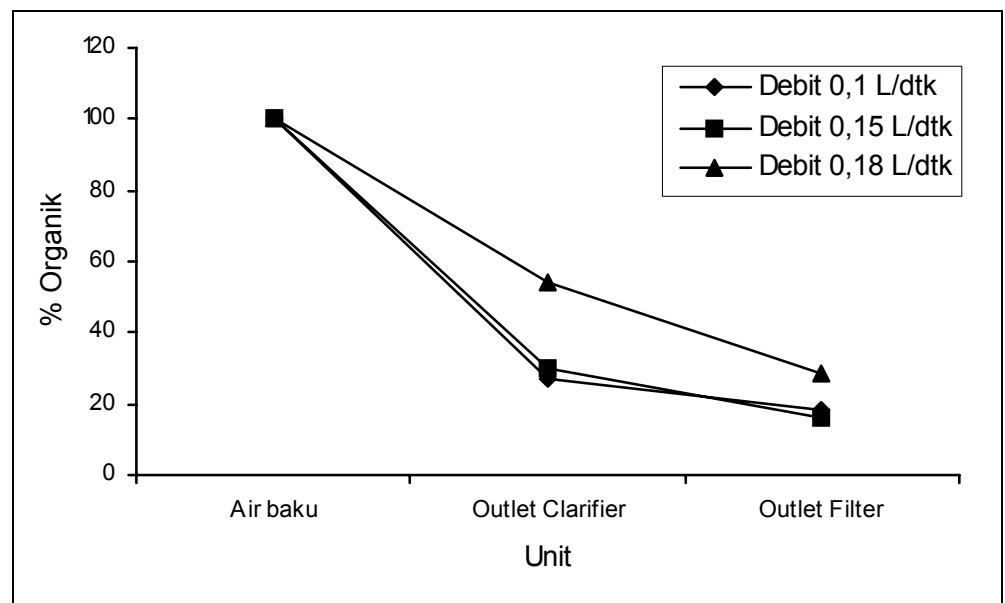

Gambar 4 Grafik penyisihan zat organik pada berbagai variasi debit.

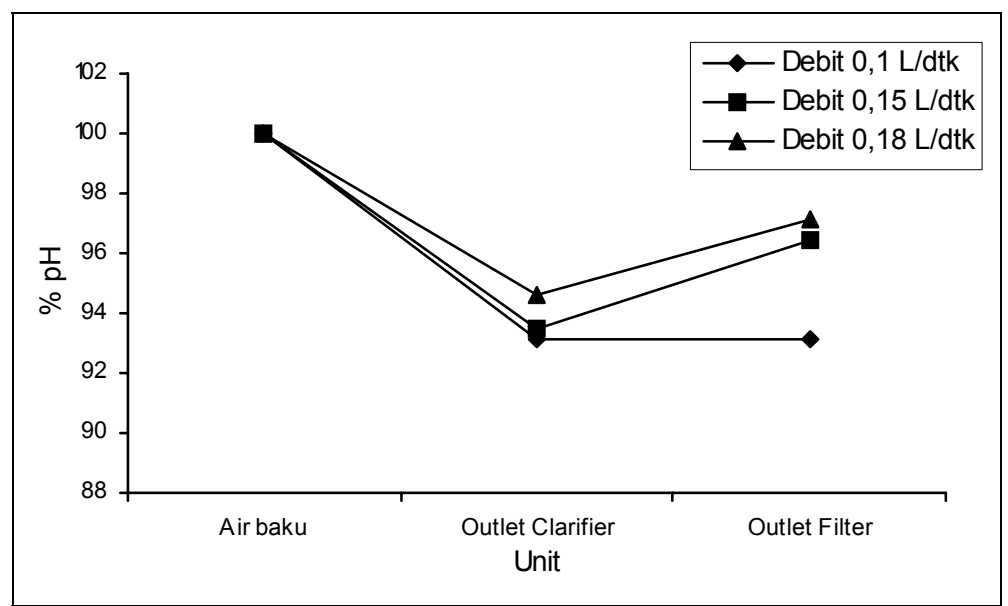

Gambar 5 Grafik fluktuasi pH pada berbagai variasi debit.

\subsection{Fluktuasi Kekeruhan, TSS, Zat Organik dan pH pada Outlet Clarifier terhadap Waktu}

\subsubsection{Debit 0,05 L/dtk}

Gambar 6 menunjukan kenaikan kekeruhan pada awal waktu operasi. Hal ini terjadi karena pada waktu tersebut selimut lumpur belum terbentuk sehingga flok-flok yang berukuran kecil masih terbawa aliran dan meningkatkan nilai kekeruhan. Setelah delapan jam terjadi penurunan kekeruhan, hal ini terjadi karena selimut lumpur telah terbentuk dan berfungsi sebagai filter kontak yang menyaring flok-flok berukuran kecil sehingga tidak terbawa aliran. 


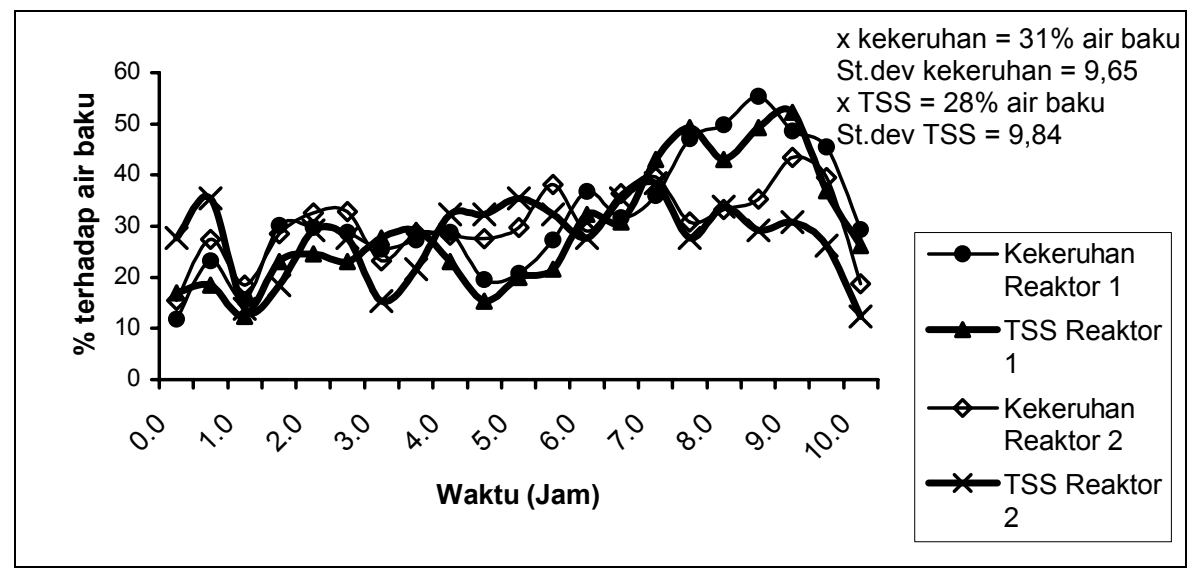

Gambar 6 Fluktuasi kekeruhan dan pH terhadap waktu pada outlet clarifier pada debit $0,05 \mathrm{~L} / \mathrm{dtk}$.

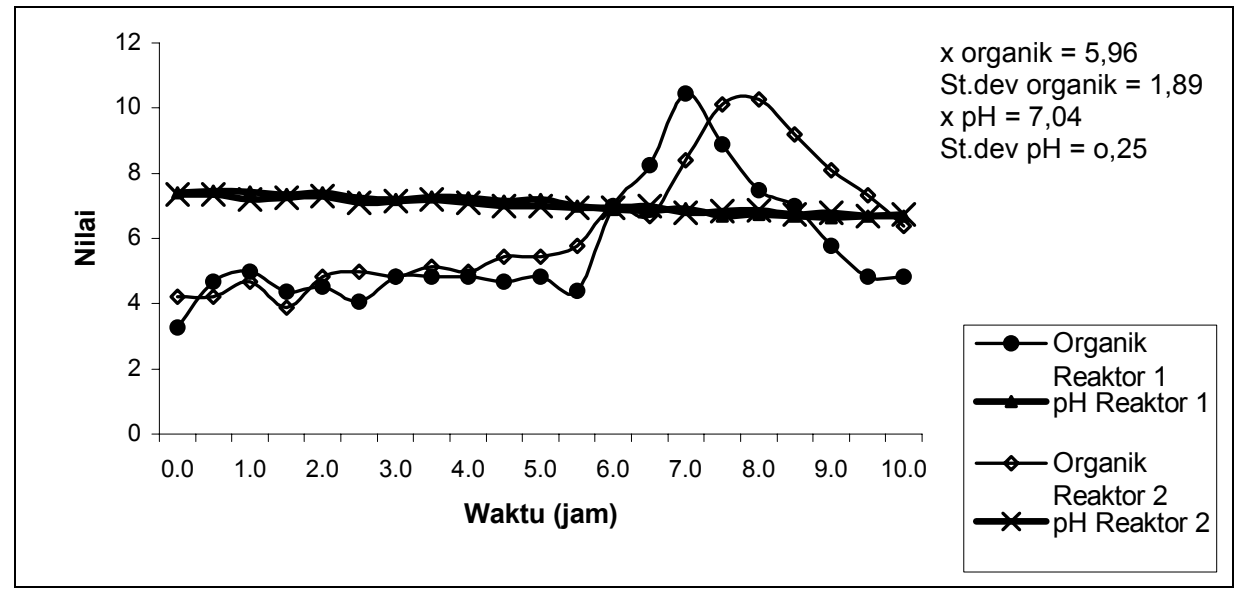

Gambar 7 Fluktuasi zat organik dan $\mathrm{pH}$ terhadap waktu pada outlet clarifier pada debit $0,05 \mathrm{~L} / \mathrm{dtk}$.

Seperti halnya pada kekeruhan pada parameter TSS pun terjadi fenomena yang sama. Pada Clarifier 1 terjadi kecenderungan peningkatan konsentrasi TSS di awal waktu operasi dan mengalami puncak setelah 7,5 sampai 9 jam, dan setelah itu mengalami penurunan yang cukup drastis. Pada Clarifier 2 konsentrasi TSS cenderung konstan di awal waktu operasi tapi kemudian mengalami penurunan setelah 8 jam. Pada gambar 7 terlihat pada debit 0,05 L/dtk, sekitar 5 jam awal proses pengolahan, terjadi pertambahan jumlah zat organik pada effluen clarifier dalam jumlah yang relatif kecil. Zat organik effluent clarifier bertambah secara cepat dan puncaknya sekitar jam ke 7 . kandungan zat organik effluen clarifier menurun dan mulai stabil kembali pada 
jam ke-9 sampai jam ke-10 yang mencapai 4,8 mg/L. Effisiensi penurunan zat organik ketika kondisi stabil mencapai 77,91\%.

\subsubsection{Debit 0,1 L/dtk}

Penurunan kekeruhan mulai terlihat setelah 7 jam pada Clarifier 1 dan setelah 6 jam pada Clarifier 2. Hal ini terjadi karena pada clarifier terjadi aliran keatas (up-flow) yang berlawanan dengan arah pengendapan. Hal ini menyebabkan terjadi tumbukan antara flok-flok yang akan mengendap dengan flok-flok kecil yang terbawa aliran, sehingga mengakibatkan terbentuknya selimut lumpur yang akan semakin tebal seiring dengan berjalannya waktu.

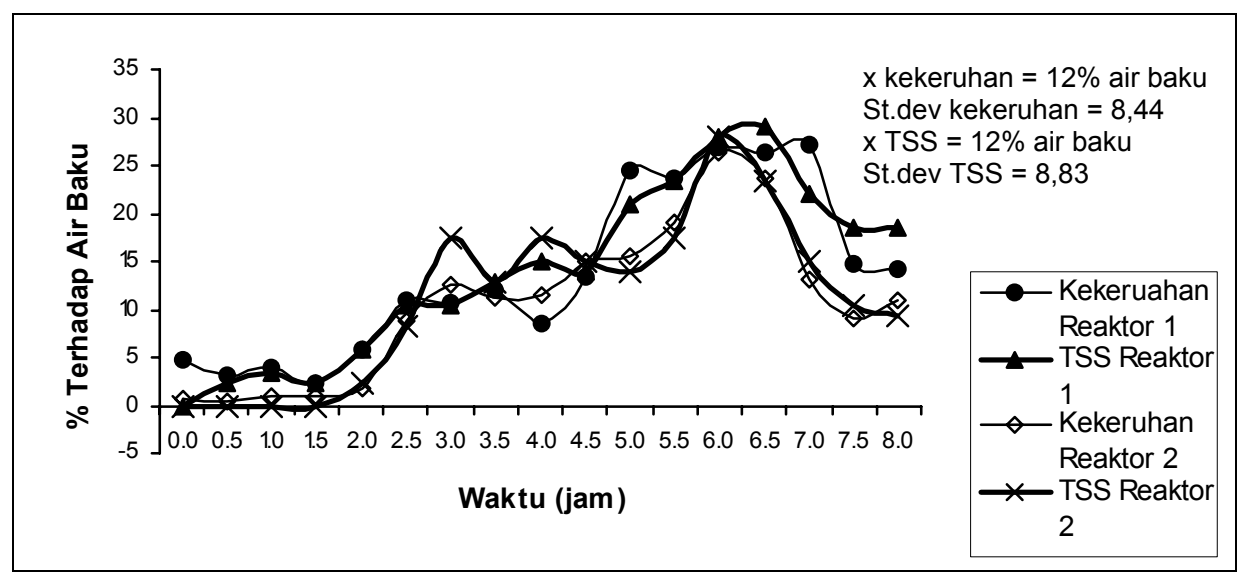

Gambar 8 Fluktuasi kekeruhan dan TSS pada outlet clarifier pada debit 0,1 L/dtk.

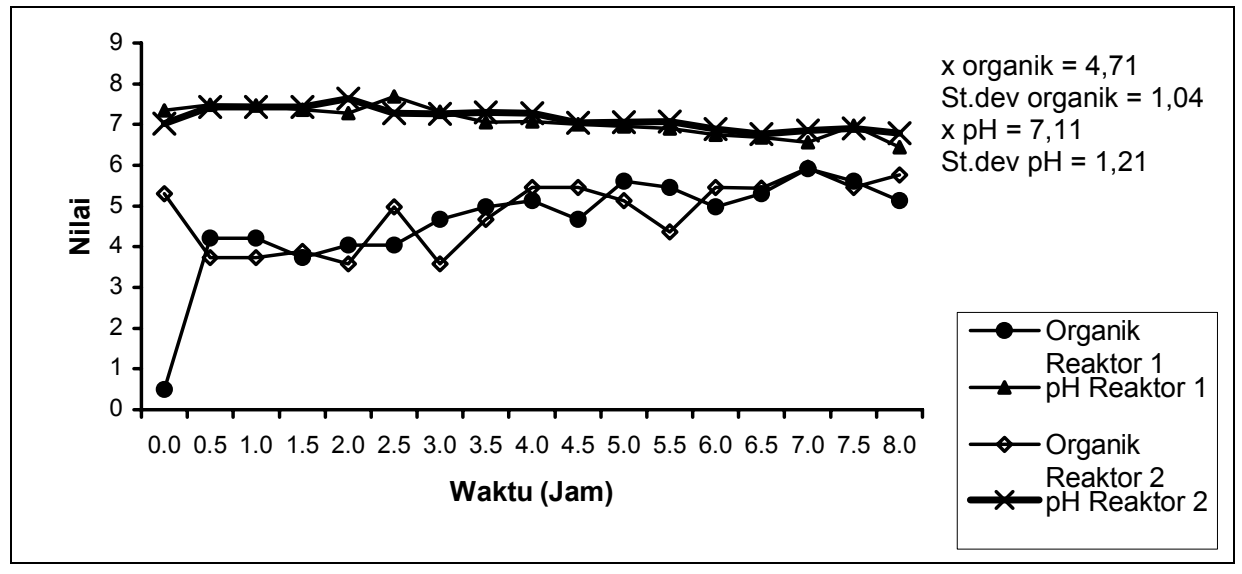

Gambar 9 Fluktuasi kandungan zat organik dan $\mathrm{pH}$ pada outlet clarifier pada debit $0,1 \mathrm{~L} / \mathrm{dtk}$. 
Kenaikan TSS terjadi selama 6 sampai 6,5 jam pertama dan diikuti dengan penurunan TSS setelahnya. Gambar 8 menggambarkan bahwa selimut lumpur telah terbentuk dengan mantap setelah 6 sampai 6,5 jam, sehingga ia dapat menyaring flok-flok kecil sehingga tidak terbawa aliran dan menurunkan konsentrasi TSS pada outlet clarifier.

Pada debit $0,1 \mathrm{~L} / \mathrm{dtk}$ terjadi penurunan zat organik dengan efisiensi $74 \%$ sampai $84 \%$. Pada penurunan organik tidak terjadi fluktuasi seperti halnya pada kekeruhan dan TSS. Sebagian besar organik telah ikut terkoagulasi dan mengendap bersama-sama flok di tangki sedimentasi. Organik yang tidak tersisihkan umumnya berbentuk terlarut sehingga tetap berada dalam air karena tidak terflokulasi. dengan waktu, $\mathrm{pH}$ memiliki kecenderungan untuk menurun, walaupun penurunannya sedikit dan kemudian berangsur konstan. Hal ini terjadi karena penambahan PAC menurunkan $\mathrm{pH}$ larutan, sampai terjadi pencampuran yang sempurna dari air didalam reaktor.

\subsubsection{Debit 0,15 L/dtk}

Kenaikan kekeruhan terjadi sampai 2,5 jam dan mengalami penurunan setelah itu. Waktu Penurunan atau waktu terbentuknya kestabilan selimut lumpur pada debit ini lebih cepat dibandingkan pada debit-debit sebelumnya sebab untuk debit yang lebih besar waktu detensinya lebih singkat dan hidraulik loadingnya lebih besar. Semakin banyak flok yang terbawa maka semakin cepat terbentuknya selimut lumpur, sehingga filter kontak yang dapat menyaring flok ringan dapat lebih cepat berfungsi.

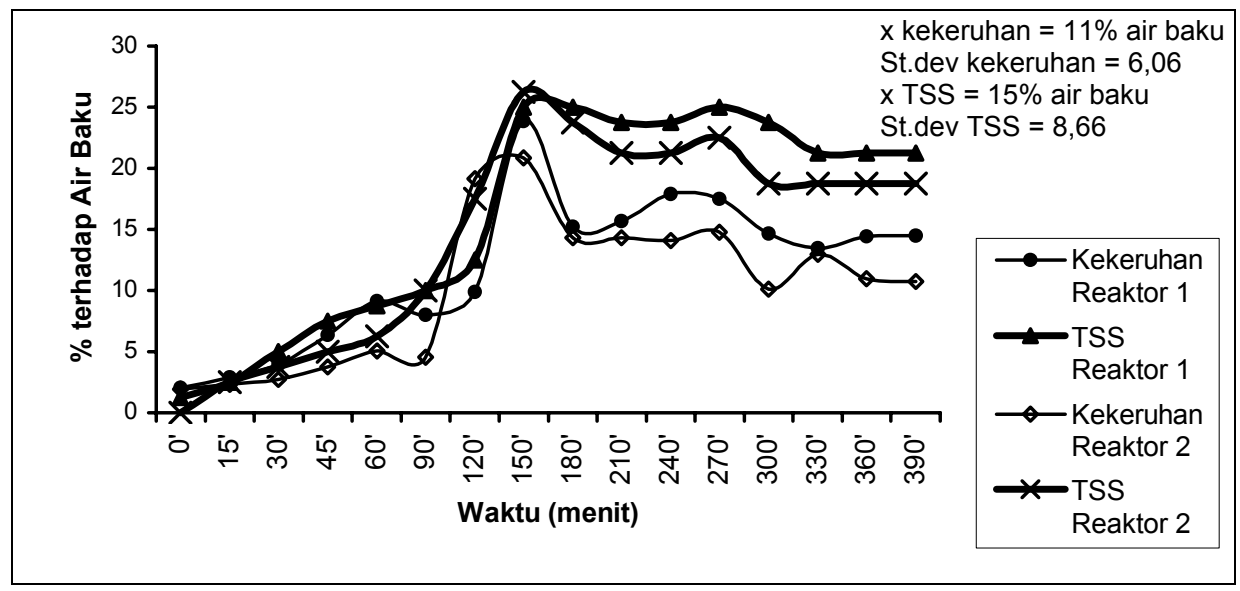

Gambar 10 Fluktuasi kekeruhan dan TSS terhadap waktu pada outlet clarifier pada debit $0,15 \mathrm{~L} / \mathrm{dtk}$. 
Dari gambar 11 terlihat, pada debit $0,15 \mathrm{~L} / \mathrm{dtk}$ kandungan zat organik pada effluen clarifier cenderung meningkat sampai dengan sekitar jam ke-3. Setelah itu kandungan zat organik effluen mulai mencapai kestabilan yang mencapai $6,538 \mathrm{mg} / \mathrm{L}$. Effisiensi penyisihan zat organik yang terjadi di clarifier mencapai $64,88 \%$.

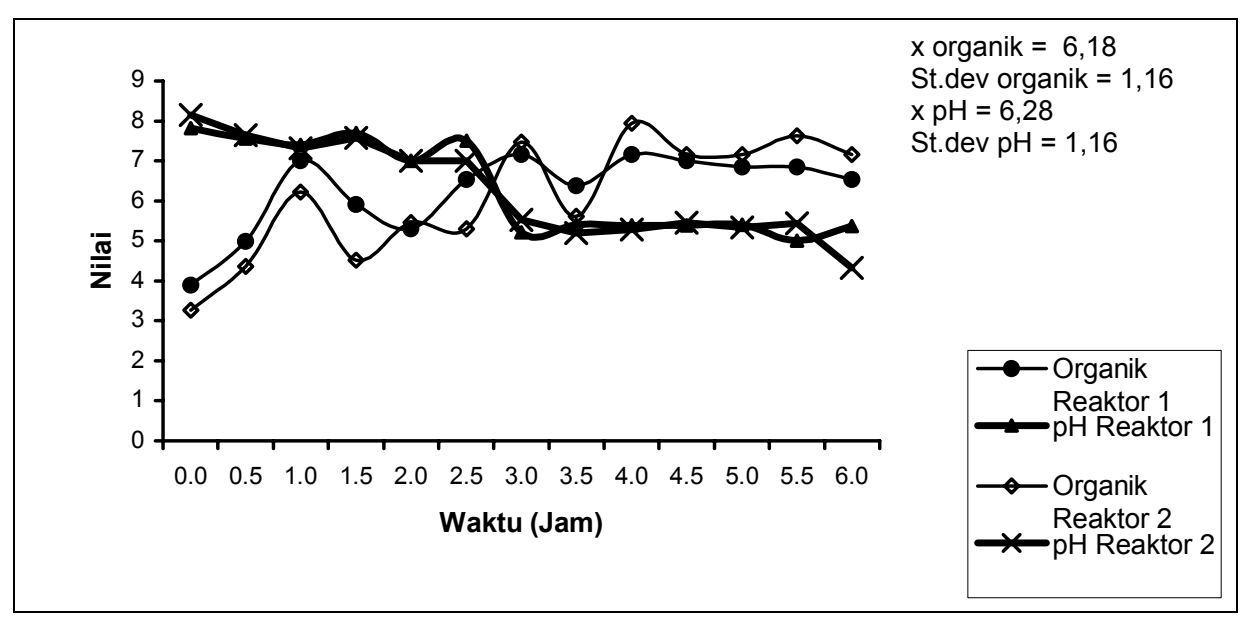

Gambar 11 Fluktuasi zat organik dan $\mathrm{pH}$ terhadap waktu pada outlet clarifier pada debit $0,15 \mathrm{~L} / \mathrm{dtk}$.

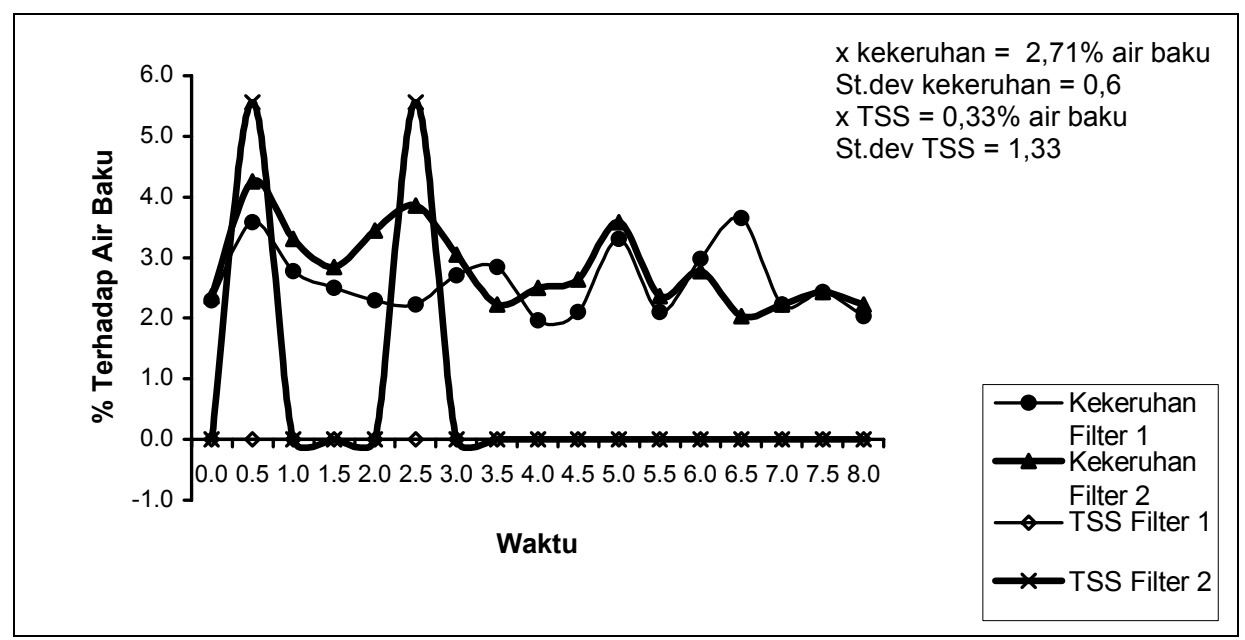

Gambar 12 Fluktuasi kekeruhan dan TSS terhadap waktu pada outlet filter pada debit $0,1 \mathrm{~L} / \mathrm{dtk}$.

Pada gambar 10 terlihat bahwa kekeruhan effluen meningkat secara gradual sampai $t=150$ menit, selanjutnya relatif konstan. Kekeruhan yang rendah pada 
saat-saat awal diduga berasal dari air di dalam reaktor yang terolah sehari sebelumnya, kemudian terendapkan selama reaktor tidak bekerja.

Pada Gambar 11 terlihat pada debit0,15 L/dtk, $\mathrm{pH}$ cenderung menurun sampai sekitar jam ke-3 dan setelah itu pH mulai stabil yaitu mencapai sekitar 5,37. Jika dibandingkan dengan $\mathrm{pH}$ air baku, yaitu 7,58 maka pada debit $0,15 \mathrm{~L} / \mathrm{dtk}$, proses pengolahan di clarifier menyebabkan penurunan $\mathrm{pH}$ yang relatif besar. Dalam grafik tidak terjadi fluktuasi atau peningkatan kadar organik seperti pada kekeruhan, karena zat organik tidak terendapkan pada saat rekator tidak bekerja, seperti halnya pada kekeruhan.

\subsection{Fluktuasi Kekeruhan, TSS, Zat Organik dan pH pada Outlet Filter terhadap Waktu pada Debit 0,1 L/dtk}

Hasil analisis kualitas pada outlet filter memperlihatkan nilai kekeruhan yang sangat baik, yaitu dibawah 0,7 NTU. Nilai ini jauh dbawah standar baku mutu yang ditetapkan untuk air minum yaitu 5 NTU.Berbeda dengan hasil pada Clarifier yang berfluktuasi, dari gambar 12 terlihat nilai kekeruhan yang stabil yaitu berkisar 0,3 NTU sampai 0,7 NTU. Ini terjadi karena filter mampu menyaring dengan baik partikel-partikel yang terbawa aliran.

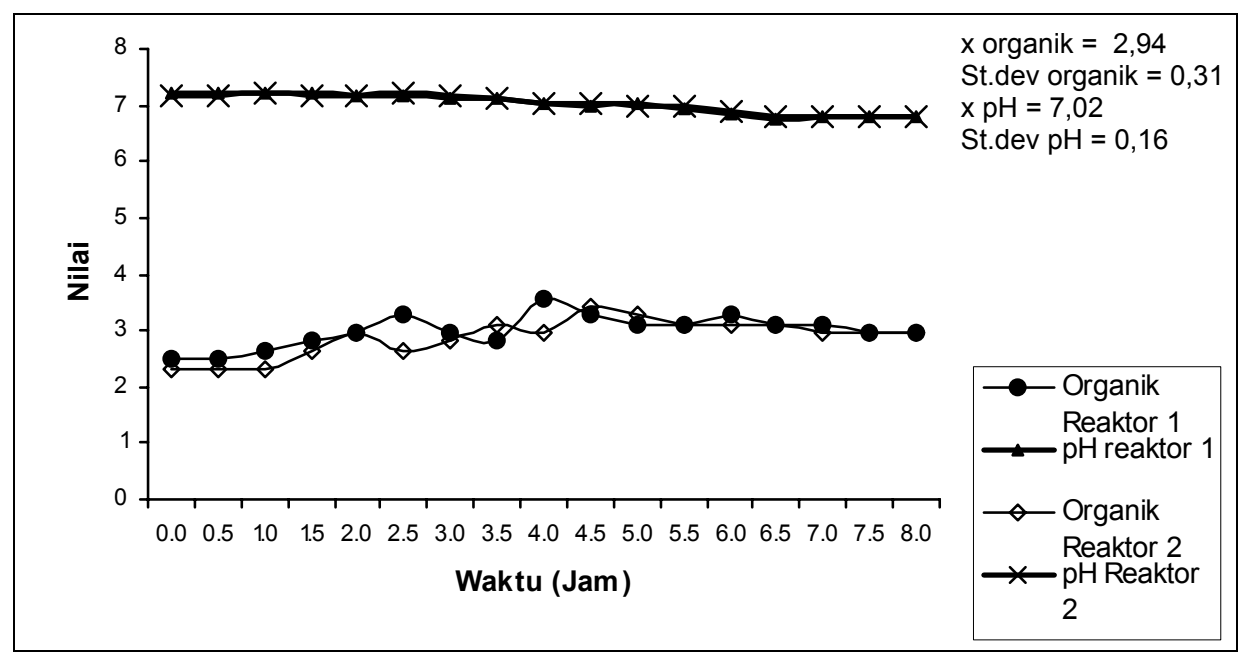

Gambar 13 Fluktuasi zat organik dan $\mathrm{pH}$ terhadap waktu pada outlet filter pada debit $0,1 \mathrm{~L} / \mathrm{dtk}$.

Seperti halnya kekeruhan, TSSpun sangat stabil pada kisaran 0 sampai $1 \mathrm{mg} / \mathrm{L}$. Hal ini menunjukan hampir seluruh suspended solid dapat disisihkan oleh filter. Suspended solid tersebut tertahan di bukaan media filtrasi atau terendapkan dipermukaan media penyaring, sehingga tidak terbawa aliran. Partikel tersebut 
akan terakumulasi dalam filter sampai suatu waktu dimana keberadaannya menyebabkan headloss yang sangat tinggi di filter, sehingga filter harus di backwash.

Pada gambar 13 terlihat pada debit $0,1 \mathrm{~L} / \mathrm{dtk}$, zat organik effluen filter meningkat dan mencapai puncak sekitar jam ke-4. setelah itu kandungan zat organik cenderung mencapai kestabilan sampai akhirnya mencapai kandungan sebesar 2,958 $\mathrm{mg} / \mathrm{L}$. Effisiensi penyisihan zat organik yang terjadi sampai dengan proses pengolahan di filter mencapai $85,41 \%$. Dari gambar tersebut juga terlihat, $\mathrm{pH}$ effluen filter cenderung mengalami penurunan dan cenderung stabil setelahjam ke-6 yang mencapai $\mathrm{pH}$ sebesar 6,79 . selama proses pengolahan sampai dengan proses filtrasi terjadi penurunan $\mathrm{pH}$ dari 7,62 sampai 6,79.

\begin{tabular}{|c|l|c|c|c|}
\hline No & Parameter & Satuan & Air Baku & Air Olahan \\
\hline 1 & Zat padat Terlarut (TDS) & $\mathrm{mg} / \mathrm{L}$ & 154 & 280 \\
2 & Kekeruhan & skala NTU & 120,6 & 0,33 \\
3 & Warna & skala TCU & 87,5 & 5 \\
4 & Zat padat tersuspensi & $\mathrm{mg} / \mathrm{L}$ & 0,27 & 0,12 \\
5 & Besi (Fe) & $\mathrm{mg} / \mathrm{L}$ & 9 & 0.151 \\
6 & Kesadahan $(\mathrm{CaCO} 3)$ & $\mathrm{mgL}$ & 73.3 & 146.6 \\
7 & Klorida $(\mathrm{Cl})$ & $\mathrm{mg} / \mathrm{L}$ & 12.61 & 112.87 \\
8 & Mangan $(\mathrm{Mn})$ & $\mathrm{mg} / \mathrm{L}$ & 0.36 & 0.036 \\
9 & Sulfat $(\mathrm{SO} 4)$ & $\mathrm{mg} / \mathrm{L}$ & 3.58 & 12.91 \\
10 & Kalsium & $\mathrm{mg} / \mathrm{L}$ & 22.77 & 3.8 \\
11 & Kalium $(\mathrm{K})$ & $\mathrm{mg} / \mathrm{L}$ & 3.57 & 38.36 \\
12 & MBAS & $\mathrm{mg} / \mathrm{L}$ & 0.524 & 0.082 \\
13 & CO2 agresif & $\mathrm{mg} / \mathrm{L}$ & 5.8 & 0 \\
14 & CO2 total & $\mathrm{mg} / \mathrm{L}$ & 8.8 & 26.5 \\
15 & Bikarbonat $(\mathrm{HCO} 3)$ & $\mathrm{mg} / \mathrm{L}$ & 114.6 & 5.67 \\
16 & Zat Organik $(\mathrm{KMnO} 4)$ & $\mathrm{mg} / \mathrm{L}$ & 37.21 & 5.16 \\
17 & COD & $\mathrm{mg} / \mathrm{L}$ & 17.56 & 3.49 \\
18 & Logam Berat & - & negatif & negatif \\
\hline
\end{tabular}

Sumber: Hasil Pengukuran

Tabel 3 Perbandingan air baku dan air olahan instalasi.

\subsection{Kualitas Air Hasil Olahan}

Tabel 3 menyajikan data kualitas air hasil olahan instalasi yang berasal dari outlet filtrasi dibandingakan dengan air baku. Dari hasil tersebut, diketahui proses pengolahan di instalasi dapat meyingkirkan beberapa kontaminan dalam air baku seperti zat padat terlarut (TDS), zat padat tersuspensi (TSS), besi, mangan, kalsium, MBAS, $\mathrm{CO} 2$ agresif, $\mathrm{CO} 2$ total, bikarbonat dan Zat Organik. 


\subsection{Nilai $G$ dan Gtd}

$G$ merupakan satuan yang berbanding lurus dengan banyaknya tumbukan sehingga semakin besar $G$ berarti semakin banyak tumbukan yang terjadi dan semakin besar ukuran flok yang terbentuk, dan karena ukuran yang besar berarti kecepatan pengendapan yang lebih besar, maka flok -flok pada debit ini lebih mudah tersisihkan.

Pada Tabel 3 dapat dilihat harga $G$ pada debit $0,05 \mathrm{~L} / \mathrm{dtk}$ untuk unit koagulasi adalah 77,1/dtk, dan untuk unit flokulasi adalah 5,9/dtk. Nilai ini jauh dibawah nilai $G$ yang dianjurkan baik oleh Reynold (1982) dan Rich (1961). Menurut Reynold nilai $G$ untuk flokulasi adalah 20/dtk sampai 50/dtk sedangkan menurut Rich nilai $G$ adalah 20/dtk sampai 70/dtk.Untuk harga kehilangan tekan yang makin besar, harga Gtd juga semakin besar. Ini karena kecepatan alirannya juga makin besar dan semakin banyak tumbukan partikel-partikel koloid yang telah terdestabilisasi, sehingga pembentukkan flok-floknya semakin baik.

\begin{tabular}{|c|c|c|c|c|c|c|c|c|c|}
\hline $\begin{array}{l}\text { Debit } \\
\text { (L/dtk) }\end{array}$ & Unit & $\begin{array}{c}\mathrm{g} \\
\left(\mathrm{m} / \mathrm{dtk}^{2}\right)\end{array}$ & hl (m) & $\mathrm{Q}\left(\mathrm{m}^{3} / \mathrm{dtk}\right)$ & $\mathrm{v}\left(\mathrm{m}^{2} / \mathrm{dtk}\right)$ & $\begin{array}{c}\mathrm{V} \\
\left(\mathrm{m}^{3}\right)\end{array}$ & $\begin{array}{c}G \\
\left(\mathrm{dtk}^{-1}\right)\end{array}$ & $\begin{array}{c}\mathrm{td} \\
(\mathrm{dtk})\end{array}$ & $\mathrm{G} \times \mathrm{td}$ \\
\hline \multirow[t]{5}{*}{0,05} & Koagulasi & $\overline{9,8}$ & $\overline{0,5}$ & 0,00005 & $8,77.10^{-7}$ & 0,047 & 77,1 & 940 & 72454 \\
\hline & Flokulasi 1 & 9,8 & 0,003 & 0,000025 & $8,77.10^{-7}$ & 0,024 & 5,9 & 480 & 5672 \\
\hline & Flokulasi 2 & 9,8 & 0,003 & 0,000025 & $8,77.10^{-7}$ & 0,024 & 5,9 & 480 & 5672 \\
\hline & Sedimentasi 1 & 9,8 & 0,003 & 0,000025 & $8,77.10^{-7}$ & 0,165 & 2,2 & 6640 & 14961 \\
\hline & Sedimentasi 2 & 9,8 & 0,003 & 0,000025 & $8,77.10^{-7}$ & 0,165 & 2,2 & 6640 & 14961 \\
\hline \multirow[t]{5}{*}{0,1} & Koagulasi & 9,8 & 0,47 & 0,0001 & $8,77.10^{-7}$ & 0,047 & 105,7 & 470 & 49672 \\
\hline & Flokulasi 1 & 9,8 & 0,008 & 0,00005 & $8,77.10^{-7}$ & 0,024 & 13,6 & 240 & 6549 \\
\hline & Flokulasi 2 & 9,8 & 0,009 & 0,00005 & $8,77.10^{-7}$ & 0,024 & 14,5 & 240 & 6946 \\
\hline & Sedimentasi 1 & 9,8 & 0,003 & 0,00005 & $8,77.10^{-7}$ & 0,165 & 3,2 & 3320 & 10579 \\
\hline & Sedimentasi 2 & 9,8 & 0,003 & 0,00005 & $8,77.10^{-7}$ & 0,165 & 3,2 & 3320 & 10579 \\
\hline \multirow[t]{5}{*}{0,15} & Koagulasi & 9,8 & 0,57 & 0,00015 & $8,77 \cdot 10^{-7}$ & 0,047 & 142,5 & 313 & 44616 \\
\hline & Flokulasi 1 & 9,8 & 0,0125 & 0,000075 & $8,77.10^{-7}$ & 0,024 & 20,9 & 160 & 6684 \\
\hline & Flokulasi 2 & 9,8 & 0,013 & 0,000075 & $8,77.10^{-7}$ & 0,024 & 21,3 & 160 & 6816 \\
\hline & Sedimentasi 1 & 9,8 & 0,0025 & 0,000075 & $8,77 \cdot 10^{-7}$ & 0,165 & 3,6 & 2214 & 7888 \\
\hline & Sedimentasi 2 & 9,8 & 0,004 & 0,000075 & $8,77.10^{-7}$ & 0,165 & 4,5 & 2214 & 9977 \\
\hline
\end{tabular}

Sumber: Hasil Perhitungan

Tabel 4 Nilai $G$ dan Gtd reaktor.

Harga Gtd untuk Koagulator adalah 44616 sampai 72454. Sedangkan untuk Flokulator adalah 5672 sampai 6816 literatur untuk mencapai kondisi optimum pembentukan flok. Nilai Gtd yang biasa digunakan adalah 12000 hingga 150000. Walaupun nilai Gtd tidak memenuhi syarat tapi flokulator telah 
menghasilkan flok-flok yang baik dan mudah mengendap. Aliran melalui media kerikil yang berliku-liku memberi kesempatan yang lebih besar bagi koloidkoloid untuk saling kontak membentuk flok. Dibandingkan dengan flokulator konvensional, harga Gtd flokulator dengan media berbutir ini ternyata tidak harus memenuhi syarat pada Tabel 4 .

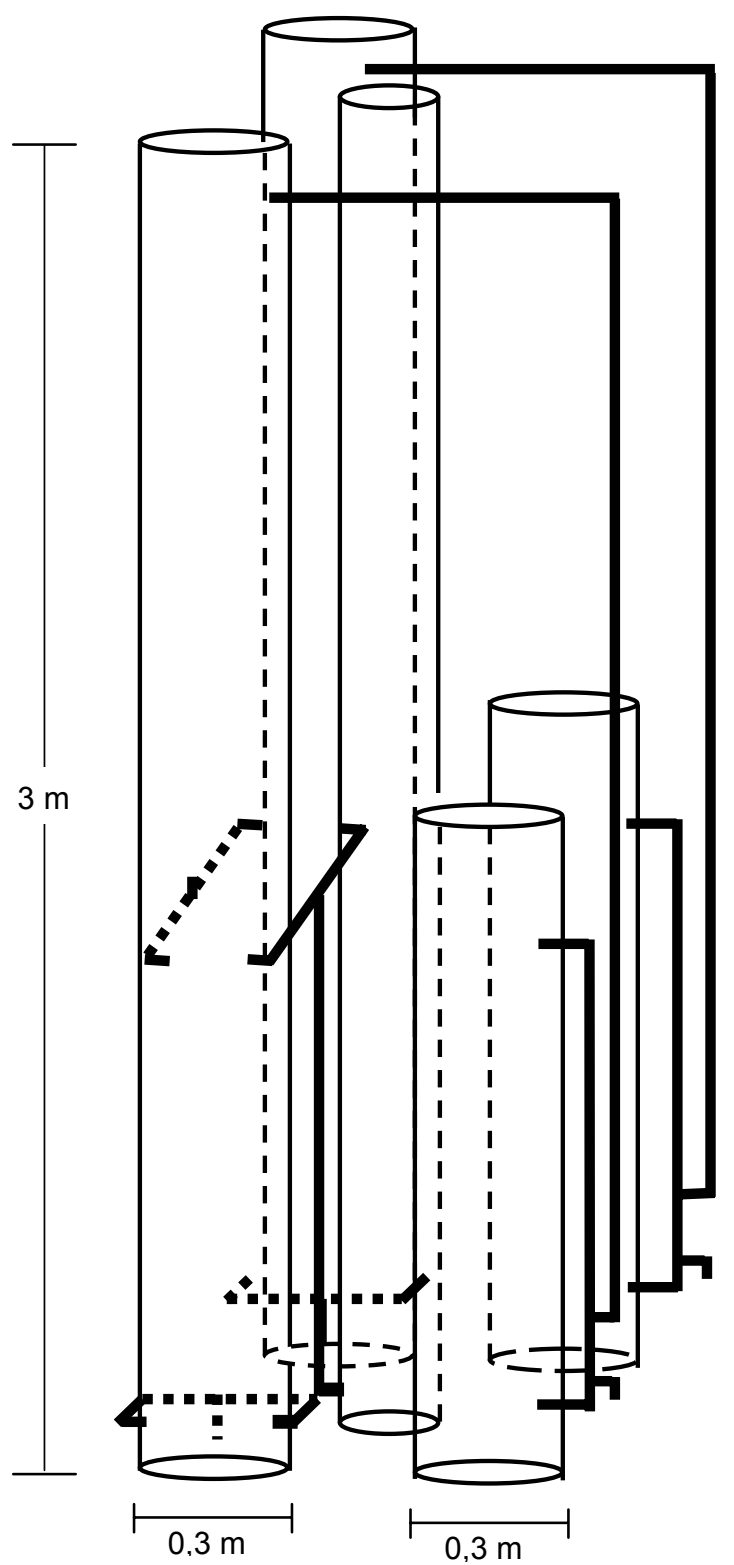

Gambar 14 Instalasi Media Berbutir Skala 1:20. 


\section{$4 \quad$ Kesimpulan}

Uji coba reaktor clarifier yang berbasis pada aliran melalui media berbutir menunjukkan hasil yang baik, dengan memenuhi standar baku mutu. Pada Clarifier terbentuk sludge blanket yang dapat menyaring flok-flok yang berukuran kecil sehingga tidak terbawa aliran, sehingga kualitas effluentnya menjadi lebih baik.

Nilai Gtd yang rendah menunjukan bahwa reaktor lebih efisien dari segi waktu kontak dan energi yang digunakan.

Dari hasil penelitian skala lapangan ini dapat disimpulkan bahwa instalasi dengan media berbutir sebagai koagulator dan flokulator menunjukan kinerja yang baik dan berpeluang untuk diaplikasikan pada pengolahan air minum.

\section{Ucapan Terima Kasih}

Penelitian ini sebagian dibiayai oleh Hibah Bersaing, u: SPK Penelitian Hibah Bersaing No. 024/P21PT/2001 tanggal 15 maret 2001, untuk itu penulis mengucapkan terima kasih yang sebesar-besarnya kepada Dep. Pendidikan Nasional RI atas bantuannya.

\section{Daftar Pustaka}

1. Armundito, Erik, Flokulasi Melalui Media Berbutir, Tugas Akhir Departemen Teknik Lingkungan ITB, Bandung (2000).

2. ASCE, AWWA, Water Treatment Plant Design, Second Edition, McGraw-Hill Inc., New York (1990).

3. Fair, G. M., Geyer, J. C. \& Okun, D. A, Water and Wastewater Engineering, Vol. 2., John Wiley \& Sons Inc., New York (1968).

4. Kawamura, Susumu, Integrated Design of Water Treatment Facilities, John Wiley \& Sons Inc., Canada (1991).

5. Notodarmodjo, Suprihanto \& Satyanegara, Donny R., KoagulasiFlokulasi dalam Media Berbutir dalam Sistem Aliran Tertutup, Jurnal Teknik Sipil, Vol. 5 No. 4, Jurusan Teknik Sipil ITB, Bandung (1998).

6. Reynold, T. D., Unit Operation and Processes in Environmental Engineering, Texas A\&M University, Texas., USA (1982).

7. $\quad$ Rich, L.G., Unit Operation of Sanitary Engineering, John Wiley \& Sons Inc., New York (1961).

8. Stumm, W. G. \& Morgan, J. J., Aquatic Chemistry, Second Edition, John Wiley \& Sons Inc., Singapore (1996). 